\title{
感圧塗料計測における誤差評価*
}

\author{
松田 佑 ${ }^{* 1}$, 山口 浩樹 $* 1$, 江上 泰広 $* 2$, 新美 智秀 $* 3$
}

\section{Error Analysis of Pressure-Sensitive Paint Measurement}

\author{
Yu MATSUDA*1, Hiroki YAMAGUCHI, Yasuhiro EGAMI and Tomohide NIIMI \\ *1 Department of Micro-Nano Systems Engineering, Nagoya University \\ Furo-cho, Chikusa, Nagoya, Aichi, 464-8603, Japan
}

Pressure-sensitive paint (PSP) is a useful measurement technique to obtain the pressure distribution on a surface, and has been applied to many measurements in wind tunnel testing. The measurement error of PSP has not been discussed in most reports, while the evaluation of the error is very important for quantitative measurements. In this study, we propose the calibration method which enables us to find the defect of PSPs or the failure of the calibration tests easily. Based on the first- and second-order polynomial Stern-Volmer equations, the propagation of error is analyzed. As a result, it is clarified that the experimental values must be fitted by the Stern-Volmer equations with the constraint condition of $\left(p / p_{\text {ref }}, I_{\text {ref }} / I\right)=(1,1)$ at $T=T_{\text {ref }}$, and the relative error in pressure can be reduced. It is also shown that the error becomes quite large when $p / p_{\text {ref }} \approx-B / 2 C$ in the second-order polynomial Stern-Volmer equation. We propose an indicator for the choice of the polynomial order of the Stern-Volmer equation at $T / T_{\text {ref }} \approx 1, p / p_{\text {ref }} \approx 1$.

Key Words : Pressure-Sensitive Paint, Pressure Measurements, Error Analysis

1. は じめ に

近年, 感圧塗料 (PSP: Pressure-Sensitive Paint) ${ }^{(1)}{ }^{(2)}$ を用いた圧力計測法は広く認知されるようになり, 樣々な流 れの計測に応用されている．しかし，PSP 計測においては計測誤差に関する議論が十分に行われているとは言い 難く, 計測精度については, PSP と同時に取得した圧力孔のデータとの比較を示すに留まることがほとんどであ る(2). しかし , PSP の最大の特徵は, PSP 塗布面での圧力を非接触に計測するところであり，圧力孔の設置が困

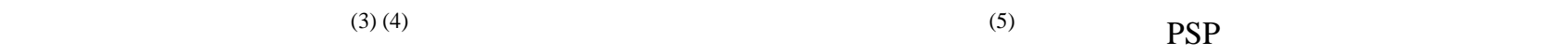
ものと考えられ，このようなa-priori な計測において定量的な議論を行うためには, PSP の計測精度に関する知 見が極めて重要となる.PSP 計測は, PSP の発光強度と圧力の関係を表す Stern-Volmer 関係式を決定する較正実 験時と，得られた Stern-Volmer 関係式と実際の流動場中での発光強度を用いて圧力分布を計測する時の 2 段階で 誤差が加わるため, 問題が複杂隹であるように考えられる.PSP 計測に関する誤差解析に言及した研究例としては， Oglesby ら ${ }^{(6)}$ Liu and Sullivan ${ }^{(2)}$ による報告が挙げられるが， これらはいずれも純粋に理論的なものであり，実際 の計測に則した誤差解析に関する議論が不足している . また彼らの研究は Stern-Volmer 関係式が最も単純な線形 の場合についてのみ調査するに留まっている . しかし, 実際の PSP では Stern-Volmer 関係式が非線形になる例が 数多く報告されており, 非線形の場合についても調査する必要がある.特に非線形の Stern-Volmer 関係式は, 線 形の Stern-Volmer 関係式に単純に 2 次の項を加え 2 次式に拡張したものが使用されているが，これは根拠となる 物理モデルのないものであり，光の使用には本来十分な注意を要するはずである．さらに通常 Stern-Volmer 係数 は較正実験によって決定されるが，この係数の決定法についても定まった手法が述べられていない．

\footnotetext{
* 原稿受付 2011 年 1 月 27 日

*1 正員, 名古屋大学大学院工学研究科マイクロナノシステム工学専攻 (†464-8603 愛知県名古屋市千種区不老町)

*2 正員, 愛知工業大学工学部

*3 正員, フェロー, 名古屋大学大学院工学研究科マイクロナノシステム工学専攻

Email:y.matsuda@nagoya-u.jp
} 
光こで本研究では, Stern-Volmer 関係式の較正実験について提案を行い, 光の後，線形及び非線形の 2 次式の Stern-Volmer 関係式によって各パラメータの相対誤差がどのように圧力の相対誤差に伝播されるのかについて調査 を行い，線形及び非線形の Stern-Volmer 関係式による圧力の相対誤差の比較を行った .

\section{PSP の測定原理}

PSP は, 酸素消光性を有する色素分子と弚れを固体表面に保持固定するためのバインダーから構成され，これを エアブラシやスピンコートなどにより模型表面に塗布して使用する . PSP は使用している色素に応じた波長の光 で励起され発光する . この励起・発光過程は, 空気中の酸素分子により消光されることにより, 酸素分圧 (酸素濃 度), ドルトンの法則によれば全圧に応じて発光強度や発光寿命が変化する.PSPによる計測法では, 一般に酸素 消光による発光強度の変化を計測する強度法と, 酸素消光による発光寿命の変化を計測する寿命法があるが, 現 在は強度法による計測が主に行われていることから，以下では強度法を念頭に議論を行う．PSP では発光強度と圧 力の関係を表す Stern-Volmer の関係式 ${ }^{(1)}(2)$ を用いることによって発光強度から圧力を算出する．

$$
\frac{I_{\text {ref }}}{I}=A(T)+B(T) \frac{p}{p_{\text {ref }}}
$$

ここでI は発光強度， $p$ は圧力であり $I_{r e f}$ は既知の圧力 $p_{r e f}$ 及び温度 $T_{r e f}$ における発光強度である．また $A(T)$ ， $B(T)$ は Stern-Volmer 係数と呼ばれる温度の関数であり, 各々の PSP において較正実験を行うことによって決定さ れる.(1) 式で示されるように, 発光強度の逆数と圧力は線形関係にある. 圧力感度を $I_{r e f} / I$ を $p / p_{\text {ref }}$ て偏微分し た量と定義すれば, 圧力感度は $B$ と表わせ , この值が大きい PSP ほど圧力感度の高い PSP であると言える.一般 に，PSP は圧力の増加につれ発光強度が低下するため, $B>0$ である。

実際の PSP においては $I_{r e f} / I$ と $p / p_{r e f}$ の間に非線形性を有するものも多く，この場合は以下の 2 次式が使用さ れる.

$$
\frac{I_{\text {ref }}}{I}=A(T)+B(T) \frac{p}{p_{\text {ref }}}+C(T)\left(\frac{p}{p_{\text {ref }}}\right)^{2}
$$

ここでも $A(T), B(T), C(T)$ は Stern-Volmer 係数と呼ばれ，やはり較正実験によって決定される .このとき圧力感 度は $B+2 C p / p_{\text {ref }}$ となり, 圧力に応じて変化する . 通常, ある圧力以上になると PSP 内の色素分子が全て消光さ れてしまい, 光れ以上の圧力では感度を有しなくなるため, PSP の圧力感度 $B+2 C p / p_{\text {ref }}$ は圧力の上昇とともに 低下する，すなわち $C<0$ である .

\section{3. 較正法について}

通常，PSP の面内では圧力感度の非一樣性は他の要因による誤差に比べ無視できるくらい小さく，同ロットの PSP 間では圧力感度は等しいと仮定する .この仮定に基づきPSP の一部分あるいは同ロットのPSP による較正実 験により，圧力分布計測が行われる．PSP の較正法には, 圧力孔と PSP を併用し複数の圧力孔と炎の近辺の PSP データを用いて較正する in-situ 法と，予めサンプル試験を行い圧力孔に頼らずに圧力算出を行う a-priori 法の $2 つ$ がある．両者とも，各圧力に対する発光強度を計測し， $I_{r e f} / I$ と $p / p_{r e f}$ を算出後，(1)，(2) 式等であてはめを行う ことにより Stern-Volmer 係数を決定する $. p / p_{\text {ref }}$ は，圧力計の值を使うことにより容易に算出できる．発光強度 については, 通常は CCD カメラで撮像し，ショットノイズ等の影響を抑えるため，ある程度大きさの領域 (画素 数)を用いて $I_{r e f} / I$ を算出する.

ここで,$I_{r e f} / I$ の算出方法に関しては 2 種類の方法が考えられる . 以下での議論においては , 較正実験に用いる 装置は文献 ${ }^{(1)}$ に述べられているような標準的なものを想定する .さらに , 較正に使用する圧力計の誤差は無視で きるくらい小さく, カメラの暗電流ノイズは減算してあり無視でき, カメラ素子への入射フォトン数と出力電子は 線形関係にあること, また励起光強度の時間変化は小さく無視できる (あるいはカメラの露光時間あるいは複数枚 の画像の平均化により炎の影響を無視することができる) 等といった系統誤差の要因は無視できるものとし，カメ ラのショットノイズ等のランダム誤差のみの影響を考えることにする．

a. 指定領域内での平均発光強度を求め $I_{r e f} / I$ を算出

この方法では，まず指定された領域内において $I$ を平均化する.$I(i, j)$ を画素 $(i, j)$ での発光強度とし，計算領 
域 $1 \leq i \leq I, 1 \leq j \leq J$ に含まれる画素数を $N=I J$ とすると, $\bar{I}$ は

$$
\bar{I}=\frac{1}{N} \sum_{i, j} I(i, j)
$$

と求められる .ここで照明ムラや PSP の塗りムラがない場合， $I(i, j)$ のヒストグラムはガウス分布と一致し， $\bar{I}$ は発光強度の最良推定値となる . また標準偏差 $\sigma_{I}$ は,

$$
\sigma_{I}=\sqrt{\frac{1}{N-1} \sum_{i, j}(I(i, j)-\bar{I})^{2}}
$$

標準誤差 $\sigma_{\bar{I}}$ は，

$$
\sigma_{\bar{I}}=\frac{\sigma_{I}}{\sqrt{N}}
$$

と与えられる .よって指定領域での発光強度は誤差も含めて，

$$
\bar{I} \pm \sigma_{\bar{I}}
$$

と書ける. 各圧力 , 温度において, このように発光強度を算出した後, 適当な圧力及び温度での発光強度を 参照状態 $\left(p_{r e f}, T_{r e f}\right)$ に選ぶことで $I_{r e f} / I\left(=\bar{I}_{r e f} / \bar{I} \pm \sigma_{\bar{I}_{r e f} / \bar{I}}\right)$ が計算される．ここで誤差 $\sigma_{\bar{I}_{r e f} / \bar{I}}$ は誤差伝播の法則 ${ }^{(7)}$ に従い計算することで得られる .

b. 各画素毎に $I_{r e f} / I$ を計算してから指定領域内で $I_{r e f} / I$ を平均化

この方法では，参照温度 $T_{r e f}$ において，指定領域内の各画素毎に $p / p_{r e f}$ に対応させて $\left(I_{r e f} / I\right)_{i, j}$ を計算する． すなわち各画素の発光強度 $I(i, j)$ を用いて

$$
\left(\frac{I_{r e f}}{I}\right)_{i, j}=\frac{I_{r e f}(i, j)}{I(i, j)}
$$

が計算でき，これを指定した領域内で平均する．すると発光強度比 $\overline{\left(I_{\text {ref }} / I\right)}$ は

$$
\overline{\left(\frac{I_{\text {ref }}}{I}\right)}=\frac{1}{N} \sum_{i, j}\left(\frac{I_{\text {ref }}}{I}\right)_{i, j}
$$

のように得られる .ここで, $\left(I_{r e f} / I\right)_{i, j}$ のヒストグラムは, 塗りムラや照明ムラで圧力感度が変わらない場合 にはガウス分布になり，この標準偏差は

$$
\sigma_{I_{\text {ref }} / I}=\sqrt{\frac{1}{N-1} \sum_{i, j}\left(\left(\frac{I_{\text {ref }}}{I}\right)_{i, j}-\overline{\left(\frac{I_{\text {ref }}}{I}\right)}\right)^{2}}
$$

と計算できる．またこの発光強度比に関する標準誤差 ${ }^{(7)}$ は，

$$
\sigma_{\overline{I_{\text {ref }} / I}}=\frac{\sigma_{I_{\text {ref }} / I}}{\sqrt{N}}
$$

となる . 弚の後 , 他の温度においても同樣の手続きで計算を行う .

以上の 2 種の方法では画素数 $N$ での議論としているが, 各圧力毎に $n$ 枚の画像を取得し光れらを平均する場合は， 適宜 $N$ を $n N$ などと変更する必要がある .ここで, 例えば計算領域の画素数 $N$ が $100 \times 100$ 画素程度あれば標準 誤差は十分小さくなり，ランダム誤差の影響をほほ排して Stern-Volmer 関係式でのあてはめが行える．また，こ れは関係式のあてはめの際に, 各圧力比における発光強度比の分散を等しいとおけ, 重みを課す必要がないこと も意味する . 両者とも参照温度 $T_{r e f}$ において $\left(p / p_{r e f}, I_{r e f} / I\right)=(1,1)$ の点を基準点としており， この点においては標 準偏差あるいは標準誤差は 0 となり，Stern-Volmer 関係式でのあてはめを行う際にはこれを拘束条件として課すべ きであることが分かる .

また $\mathrm{a}$ と b の手法の違いは計算順序の違いであり, $\mathrm{a}$ の場合は各圧力毎にある領域内の発光強度を平均化するこ とによって, 塗りムラの影響等が無視できる場合には, 兴の圧力下での発光強度の最良推定値を計算し，圧力感 
度を計算することに相当する，一方，b の場合は各画素毎に圧力感度を計算し，ある領域において光れらを平均化 することによって圧力感度を計算することになり，これは疑似的に複数のサンプル試験を行い，圧力感度の最良 推定值を計算することに相当する . 一見すると a と b とでは計算順の違いにより得られる結果が異なることが考 えられるが, 最初に仮定したようにPSP 面内では圧力感度はほぼ一樣であり，光の感度に応じて各圧力下で各画 素での発光強度が得られることになるため, $a, b$ のどちらでも最終的には標準誤差内で同じ圧力感度が得られる． 両者の処理によって得られる結果がお互いの標準誤差を大きく外れる場合は，画像内に電子飽和している画素が ないか等の較正実験上の不備を疑うべきである . 圧力感度は PSP の塗りムラや励起光の照明么ラによって変化し ないとすれば，b の方法の (7) 式で得られる $\left(I_{r e f} / I\right)_{i, j}$ のヒストグラムはガウス分布に一致するため, サンプル試験 時に作製した PSP の不良を発見し易い，すなわち，ガウス分布を外れる場合には，例えば色素の凝集や励起光が 強すぎることによって光劣化等が生じている等の原因により，この仮定が成立しなくなっていることが考えられ， このような圧力感度が非一樣となるようなPSP では高精度な圧力分布計測は期待できない . 一方 , a の手法の場 合は，発光強度のヒストグラムを見ることになるが，これは塗りムラや照明ムラ等の影響のため，通常はガウス 分布にならず, 較正実験での不備の発見には不向きである .

\section{4. 圧力計測における誤差解析}

較正実験等によって得られた $I_{r e f} / I$ と $p / p_{r e f}$ の関係を (1)，(2) 式等の Stern-Volmer 関係式であてはめることによ り Stern-Volmer 係数が決定される．弚の後，通常の強度法による計測では風洞試験等により，無風時の圧力 $p_{r e f}$, 無風時の発光強度画像を $I_{r e f}$, 通風時画像 $I$ として, Stern-Volmer 関係式を $p$ について各画素毎に解くことにより圧 力分布画像が得られる .したがって PSP 計測によって得られる圧力については Stern-Volmer 関係式に従って誤差が 伝播される.すなわち Stern-Volmer 関係式に現れる変数, 発光強度 $I, I_{r e f}$, 参照状態での圧力 $p_{r e f}$, Stern-Volmer 係数 $A, B, C$ ，及び温度 $T$ の誤差が圧力 $p$ の誤差に伝播される。

\subsection{Stern-Volmer 関係式が線形式で与えられる場合}

\subsection{1 発光強度の誤差が圧力誤差に与える影響}

較正実験の結果が線形式で良く近似できる場合，すなわち Stern-Volmer 関係式が (1) 式で与えられる場合につい て考える . まずは発光強度の計測誤差が圧力の誤差に与える影響を考える. 発光強度は参照状態 (無風時) での発 光強度 $I_{r e f}$ 及び通風時の発光強度 $I$ があり, 圧力 $p$ の誤差を $\Delta p, I_{r e f}$ の誤差を $\Delta I_{r e f}, I$ の誤差を $\Delta I$ と書けば, 発 光強度 $I$ の計測誤差による圧力 $p$ の相対誤差 $\Delta p / p$ は

$$
\left(\frac{\Delta p}{p}\right)_{I}=\sqrt{\left(\frac{I_{\text {ref }}}{p} \frac{\partial p}{\partial I_{\text {ref }}} \frac{\Delta I_{\text {ref }}}{I_{\text {ref }}}\right)^{2}+\left(\frac{I}{p} \frac{\partial p}{\partial I} \frac{\Delta I}{I}\right)^{2}}
$$

と書ける .ここで $I$ と $I_{r e f}$ の間には相関はないとした .すなわち， $\Delta I_{r e f}, \Delta I$ はショットノイズによるランダム誤

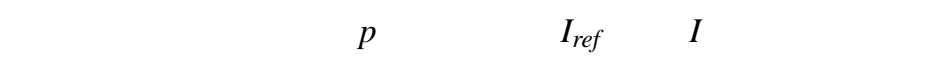

$$
\begin{gathered}
\frac{\partial p}{\partial I_{\text {ref }}}=\frac{p_{\text {ref }}}{I B} \\
\frac{\partial p}{\partial I}=-\frac{I_{\text {ref }} p_{\text {ref }}}{I^{2} B}
\end{gathered}
$$

となる (11) 式に (12)，(13) 式を代入し，(1)式を用いると， $I_{r e f}, p_{r e f}, B$ は正であるので，

$$
\left(\frac{\Delta p}{p}\right)_{I}=\frac{I_{\text {ref }} / I}{I_{\text {ref }} / I-A} \sqrt{\left(\frac{\Delta I_{\text {ref }}}{I_{\text {ref }}}\right)^{2}+\left(\frac{\Delta I}{I}\right)^{2}}
$$

のように変形出来る .ここで, $\Delta I_{r e f}, \Delta I$ はショットノイズによるものと考えると $, \Delta I_{r e f} / I_{r e f}, \Delta I / I$ は SN 比の逆 数に相当する.すなわち, カメラ素子上において単位時間当たりに $E$ の信号電荷が発生し, 素子上で時間 $t$ 蓄積 されるとき，

$$
S N R=\sqrt{t E}
$$


と書ける .ここで $t E$ はカメラ上で捉える発光強度に比例するので

$S N R \propto \sqrt{I}$

と書け， $\Delta I / I$ は比例定数 $\alpha$ を用いて，

$$
\frac{\Delta I}{I}=\frac{\alpha}{\sqrt{I}}
$$

と書ける．ただしここでは先述のように入射光子数とカメラの出力が線形関係にあると考えている. $\Delta I_{\text {ref }} / I_{\text {ref }}$ に ついても同樣に, 同一のカメラを用いることからやはり比例係数は $\alpha$ となり，これらの関係を (14) 式に代入して 整理すると

$$
\begin{aligned}
\left(\frac{\Delta p}{p}\right)_{I} & =\frac{I_{\text {ref }} / I}{I_{\text {ref }} / I-A} \sqrt{\frac{\alpha^{2}}{I_{\text {ref }}}+\frac{\alpha^{2}}{I}} \\
& =\frac{\alpha}{\sqrt{I_{\text {ref }}}} \frac{I_{\text {ref }} / I}{I_{\text {ref }} / I-A} \sqrt{1+\frac{I_{r e f}}{I}}
\end{aligned}
$$

が得られる . (17) 式は $p / p_{\text {ref }}$ についての式に書き換えることができ，

$$
\begin{aligned}
\left(\frac{\Delta p}{p}\right)_{I} & =\frac{\alpha}{\sqrt{I_{r e f}}} \frac{A+B p / p_{\text {ref }}}{B p / p_{\text {ref }}} \sqrt{1+A+B \frac{p}{p_{\text {ref }}}} \\
& =\frac{\alpha}{\sqrt{I_{\text {ref }}}} \frac{A+B \mathcal{P}}{B \mathcal{P}} \sqrt{1+A+B \mathcal{P}}
\end{aligned}
$$

となる .ここで見易さのため, $P=p / p_{\text {ref }}$ とおいた . (18) 式から, $\mathcal{P} \rightarrow 0 て ゙ ~(\Delta p / p)_{I} \rightarrow \infty$ となり，低圧での圧力計測 は誤差が大きくなり不適当であることが分かる .これは低圧になると圧力 $p$ 弚のものが小さくなるために , 誤差が 相対的に大きくなることを意味している. 実際のPSP のデータを代入してプロットしたグラフが図 1 である. 図 1 では , Liu ら ${ }^{(2)}$ に示されているPSPのうち 3 つの PSP , PtTFPP/FIB( $\left.A=0.13, B=0.87\right), \operatorname{PtTFPP} /$ silica gel $(A=0.27$, $B=0.72)$, Perylene/silica gel $(A=0.47, B=0.53)$ についてプロットしており，横軸は $P$, 縦軸は圧力の相対誤差に 参照状態での発光強度の平方根を乗じた $\sqrt{I_{r e f}}(\Delta p / p)_{I}$ であり，ここでは比例定数 $\alpha=1$ とおいた . またいずれの PSP も $p_{r e f}=100 \mathrm{kPa}, T_{r e f}=293 \mathrm{~K}$ である . 3 つのグラフを比較すると, PtTFPP/FIB，すなわち圧力感度 $B$ の大き なPSP が相対誤差が小さいことが分かる . また 3 つのPSP は圧力感度が上昇するにつれ，誤差が極小となるPが 小さくなることが分かり，弚れ以下の圧力では誤差が急激に大きくなることが分かる . 例えば， PtTFPP/FIB では $\boldsymbol{P}<0.2$ のような低圧では相対誤差が急激に大きくなるため，このような圧力範囲での計測は不適当である．また， PtTFPP/FIB 及び PtTFPP/silica gel では, 誤差が極小となる圧力より高圧側で徐々に誤差が大きくなることが分か る . これは圧力 $p$ が上昇するにつれ発光強度 $I$ が低下し SN 比が低下することによるものであり， $\Delta I / I$ に由来する (18) 式における $\sqrt{1+A+B \mathcal{P}}$ なる項のうちの $B \mathcal{P}$ にるるものである . 同樣の傾向は Perylene/silica gel においても やはり高圧側で生じている，すなわち，圧力感度の高いPSP の方が, 圧力の増大に伴う発光強度の減少量が大き く，SN 比が低下するため，圧力感度の高いPSPにおいてこの影響は顕著に見られる．しかし，以上のような SN 比の低下の影響がみられるにも関わらず，広い圧力範囲において圧力感度の高い PSP の方が優位であることは注 目に值する.

4.1.2 参照圧力 $p_{r e f}$ の誤差が圧力誤差に与える影響

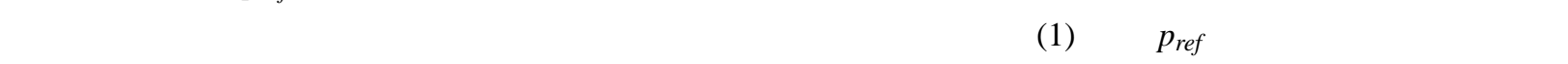

$$
\frac{\partial p}{\partial p_{\text {ref }}}=\frac{I_{\text {ref }}}{I B}-\frac{A}{B}=\frac{p}{p_{\text {ref }}}
$$

となり，圧力 $p$ の相対誤差 $\Delta p / p$ は，

$$
\left(\frac{\Delta p}{p}\right)_{p_{\text {ref }}}=\frac{p_{\text {ref }}}{p}\left|\frac{\partial p}{\partial p_{\text {ref }}}\right| \frac{\Delta p_{\text {ref }}}{p_{\text {ref }}}=\frac{\Delta p_{\text {ref }}}{p_{\text {ref }}}
$$

と書ける.このことから，圧力 $p$ の相対誤差は参照圧力 $p_{r e f}$ の相対誤差に等しくなる．一般に $\Delta p_{r e f} / p_{r e f}$ は高精 度な圧力計を使用することによって十分に小さくできるため，この影響は無視できることが多い． 


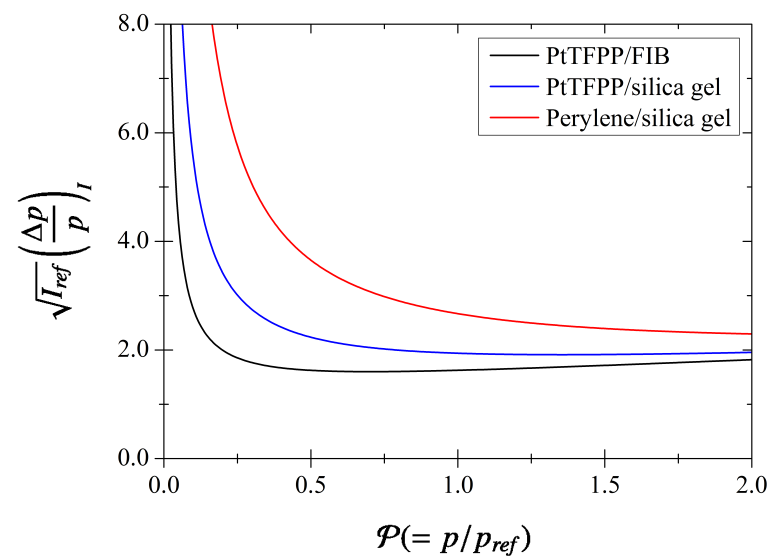

Fig. 1 Relative error in pressure as a function of normalized pressure for the three $\mathrm{PSP}, \operatorname{PtTFPP} / \operatorname{FIB}(A=$ $0.13, B=0.87)$, PtTFPP/silica gel $(A=0.27, B=0.72)$, and Perylene/silica gel $(A=0.47, B=0.53)$.

\subsubsection{Stern-Volmer 係数の誤差が圧力誤差に与える影響}

(1) 式中の Stern-Volmer 係数は較正実験によって決定されるが, 実験値のあてはめを行う際に Stern-Volmer 係数 には推定誤差が生じる .この Stern-Volmer 係数の誤差が圧力の相対誤差へ与える影響について議論する . (1) 式を $A, B$ について偏微分すると，

$$
\begin{aligned}
& \frac{\partial p}{\partial A}=-\frac{p_{\text {ref }}}{B} \\
& \frac{\partial p}{\partial B}=-\frac{I_{\text {ref }} p_{\text {ref }}}{I B^{2}}+\frac{A p_{\text {ref }}}{B^{2}}=-\frac{p}{B}
\end{aligned}
$$

である.ここで 2 変数データに対して回帰直線を求める場合, 測定值を規定する量 $($ 今の場合 $P$ ) が正のとき,一般に 未知パラメータ間には負の相関があることが言える ${ }^{(8)}$.さらに今 , 圧力感度 $B>0$ であることから $(\partial p / \partial A)(\partial p / \partial B)>0$ である．このとき $A, B$ による圧力の相対誤差は，光れ光れによる誤差の 2 乗和の平方根よりも小さくなる . しか し, 実際の直線のあてはめを行うソフトウェアには，これらのパラメータの誤差行列まで出力しないものも多く， Stern-Volmer 係数 $A, B$ 間の共分散は別途計算が必要なことが多い，光こでここでは圧力 $p$ の相対誤差 $(\Delta p / p)_{A, B}$

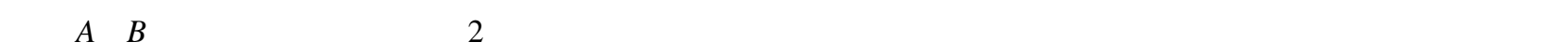
はなっても過少に評価することはない，すなわち，

$$
\begin{aligned}
\left(\frac{\Delta p}{p}\right)_{A, B} & =\sqrt{\left(\frac{A}{p} \frac{\partial p}{\partial A} \frac{\Delta A}{A}\right)^{2}+\left(\frac{B}{p} \frac{\partial p}{\partial B} \frac{\Delta B}{B}\right)^{2}} \\
& =\sqrt{\frac{A^{2}}{B^{2}} \frac{1}{\mathcal{P}^{2}}\left(\frac{\Delta A}{A}\right)^{2}+\left(\frac{\Delta B}{B}\right)^{2}}
\end{aligned}
$$

となる .このとき, 圧力 $p$ の相対誤差 $(\Delta p / p)_{A, B}$ は, 圧力に関して減少関数となっていることが分かる . また圧力 感度 $B$ が大きいPSP の方が圧力の相対誤差の小さな計測が可能であることが分かる .

3 章において指摘したが, Stern-Volmer 係数を決める際, 実験値は参照温度 $T_{\text {ref }}$ において $\left(p / p_{\text {ref }}, I_{r e f} / I\right)=(1,1)$ を基準点として整理されており，この点を通るようにあてはめを行うべきである.$A\left(T_{r e f}\right) を A_{r e f}$ などと表わすこ とにすれば，このとき，(1) 式は $A_{r e f}+B_{r e f}=1$ を代入して，

$$
\frac{I_{r e f}}{I}=1-B_{r e f}+B_{r e f} \frac{p}{p_{r e f}}
$$

と書け，これを $B_{r e f}$ につて偏微分すると，

$$
\frac{\partial p}{\partial B_{r e f}}=\frac{p_{r e f}}{B_{r e f}}\left(1-\frac{p}{p_{r e f}}\right)
$$


となり，圧力 $p$ の相対誤差 $\Delta p / p$ は，

$$
\left(\frac{\Delta p}{p}\right)_{B}=\frac{B_{r e f}}{p}\left|\frac{\partial p}{\partial B_{\text {ref }}}\right|\left(\frac{\Delta B_{r e f}}{B_{r e f}}\right)_{B}=\left|\frac{1}{\mathcal{P}}-1\right|\left(\frac{\Delta B_{r e f}}{B_{r e f}}\right)_{B}
$$

と書ける . (22) 式から $P=1$ では, 圧力の相対誤差は 0 となること, さらに Stern-Volmer 係数に依存しないこと が分かる . また拘束条件 $A_{r e f}+B_{r e f}=1$ を課さない場合の参照温度 $T_{r e f}$ での圧力の相対誤差は , (20) 式における $A$, $B$ を $A_{r e f}, B_{r e f}$ に置き換えて

$$
\left(\frac{\Delta p}{p}\right)_{A, B}=\sqrt{\frac{A_{r e f}^{2}}{B_{r e f}^{2}} \frac{1}{\mathcal{P}^{2}}\left(\frac{\Delta A_{r e f}}{A_{r e f}}\right)^{2}+\left(\frac{\Delta B_{r e f}}{B_{r e f}}\right)^{2}}
$$

で与えられる．ここで一般に，(22) 式中の $\left(\Delta B_{r e f} / B_{r e f}\right)_{B}$ は拘束条件を課すため，(23) 式中の $\left(\Delta A_{r e f} / A_{r e f}\right)_{A, B}$, $\left(\Delta B_{r e f} / B_{r e f}\right)_{A, B}$ に比べ大きな值をとる点に注意する必要がある . (23) , (22) 式を比べると

$$
\left(\frac{\Delta B_{r e f}}{B_{r e f}}\right)_{B}<\frac{1}{|1-\mathcal{P}|} \sqrt{\frac{A_{r e f}^{2}}{B_{r e f}^{2}}\left(\frac{\Delta A_{r e f}}{A_{r e f}}\right)^{2}+\mathcal{P}^{2}\left(\frac{\Delta B_{r e f}}{B_{r e f}}\right)^{2}}
$$

のとき，拘束条件を課した (22) 式によって与えられる圧力の相対誤差が拘束条件を課さない (23) 式によって与 えられる誤差よりも小さくなる. (24) 式を見ると, 参照温度 $T_{r e f}$ 近傍においては, $\mathcal{P} \approx 1$ では $\left(\Delta B_{r e f} / B_{r e f}\right)_{B}$ が $\left(\Delta A_{r e f} / A_{r e f}\right)_{A, B},\left(\Delta B_{r e f} / B_{r e f}\right)_{A, B}$ に比べかなり大きい場合においてさえ，(1) 式に拘束条件として $A_{r e f}+B_{r e f}=1$ を課 した方が有利であることが分かる．

4.1.4 温度の誤差が圧力誤差に与える影響

(21) 式を温度 $T$ に関して偏微分すると，

$$
\frac{\partial p}{\partial T}=\frac{p_{\text {ref }}}{B}\left(-\frac{\partial A}{\partial T}-\frac{p}{p_{\text {ref }}} \frac{\partial B}{\partial T}\right)
$$

が得られ，これから圧力 $p$ の相対誤差 $\Delta p / p$ は，

$$
\left(\frac{\Delta p}{p}\right)_{T}=\frac{T}{p}\left|\frac{\partial p}{\partial T}\right| \frac{\Delta T}{T}=\frac{T}{B \mathcal{P}}\left|-\frac{\partial A}{\partial T}-\mathcal{P} \frac{\partial B}{\partial T}\right| \frac{\Delta T}{T}
$$

と書ける . (25) 式から圧力感度が高く, 圧力感度の温度依存性が小さい方か計測に有利であることが分かる．

$4 \cdot 2$ Stern-Volmer 関係式が非線形式で与えられる場合

(2) 式を用いる場合は厳密には実験点のあてはめに 2 次式を使用すべきかどうか検定を行うべきである . 簡単な 指標として，Stern-Volmer 係数に大きな值が含まれる場合，あるいは Stern-Volmer 係数の誤差が大きくなる場合は オーバーフィッティングを行っている可能性があるため，乥の近似の妥当性を検定等を行い評価すべきである . 以 下では (2) 式による近似が適切であるものとして議論を進める .

\subsection{1 発光強度の誤差が圧力誤差に与える影響}

対象とする圧力範囲が小さい場合, Stern-Volmer 関係式は (1) 式のように線形式であるが, 対象となる圧力が広 範になると，Stern-Volmer 関係式は非線形となり (2) 式を用いる必要が出てくる. (2) 式を光れ光れ発光強度 $I_{r e f}$, $I$ で偏微分すると，

$$
\begin{aligned}
\frac{\partial p}{\partial I_{\text {ref }}} & =\frac{p_{\text {ref }}}{I\left(B+2 C p / p_{\text {ref }}\right)}=\frac{p_{\text {ref }}\left(A+B \mathcal{P}+C \mathcal{P}^{2}\right)}{I_{\text {ref }}(B+2 C \mathcal{P})} \\
\frac{\partial p}{\partial I} & =-\frac{I_{\text {ref }} p_{\text {ref }}}{I^{2}\left(B+2 C p / p_{\text {ref }}\right)}=-\frac{p_{r e f}\left(A+B \mathcal{P}+C \mathcal{P}^{2}\right)}{I(B+2 \mathcal{P})}
\end{aligned}
$$

が得られる $4 \cdot 1 \cdot 1$ 項の議論と同樣に，(11) 式にこれらの偏微分を代入すると，圧力 $p$ の相対誤差 $\Delta p / p$ は,

$$
\begin{aligned}
\left(\frac{\Delta p}{p}\right)_{I} & =\frac{1}{\mathcal{P}} \frac{A+B \mathcal{P}+C \mathcal{P}^{2}}{B+2 C \mathcal{P}} \sqrt{\frac{\alpha^{2}}{I_{r e f}}+\frac{\alpha^{2}}{I}} \\
& =\frac{\alpha}{\sqrt{I_{r e f}}} \frac{A+B \mathcal{P}+C \mathcal{P}^{2}}{(B+2 C \mathcal{P}) \mathcal{P}} \sqrt{1+A+B \mathcal{P}+C \mathcal{P}^{2}}
\end{aligned}
$$


と書ける .ここで(2) 式及び圧力感度はともに正，すなわち $A+B \mathscr{P}+C P^{2}>0 ， B+2 C \mathscr{P}>0$ であることを用いた . この式に Puklin ら ${ }^{(9)}($ PtTFPP/FIB : $A=0.096, B=1.081, C=-0.187)$ のデータを代入すると図 2 のようになる. 比較のため, 図 1 に示した同じ PtTFPP/FIB について (1) 式で近似したもの $(A=0.13, B=0.87)$ を示す . 両者とも $p_{r e f}=100 \mathrm{kPa}$ である . 横軸はP , 縦軸は圧力の相対誤差に参照状態での発光強度の平方根をかけた $\sqrt{I_{r e f}}(\Delta p / p)_{I}$ であり，ここでは比例定数 $\alpha=1$ とした .また，(2) 式および(1) 式による Stern-Volmer の関係式を図 3 に示す . 図 3 から分かるように，両者はP $\leq 1$ で良く一致する一方，P>1では大きく異なる傾向を示す . これは Puklin らの データはP $\leq 1$ での実験点を(2) 式によりあてはめているためである .

図 2 において両者が良く一致するP $\leq 1$ の範囲に注目する .ここで示されている結果は，発光強度の相対誤差が 圧力の相対誤差に与える影響であり，両者を単純に比較できないことに注意しなければならない，すなわち，(2)式 による実験值の補間による方が，最小 2 乗近似を行う際に (1) 式によるものに比べ実験值に対する残差 2 乗和を明 らかに低減させることができる点に注意しなければならない . 図 2 から , 低圧部 $(\mathcal{P}<0.4)$ においては (2) 式によっ て Stern-Volmer 係数を決定した場合の方が圧力の相対誤差を小さく出来ることが分かる．これは，Stern-Volmer 関 係式に (2) 式を用いることによって，低圧側で計測精度を高くできる可能性があることを意味している．ただし 両者ともに $P=0$ で相対誤差が発散することに注意しなければならない，一方，0.5<P<1.0では (1) 式による場 合の方が相対誤差が小さくなっている．これは，P $\leq 1$ において (1)，(2) 式が良く一致することを考えると，(18)， (26) 式中の分母の違いによるものと考えられる . すなわち (2) 式による $0.5<P<1$ での誤差の増大は (26) 式の分 母に現れる $B+2 C P$ の項の影響であることが分かる. (26) 式によれば(2)式を用いる場合 , $P=-B / 2 C=2.89$ にお いて圧力の相対誤差が発散するが，この影響がP >0.5 で現れていると考えられる．

次にP>1の場合について考える.この範囲においては, Puklin らのデータで議論することは適切ではないと考 えられるが , ここでは較正実験を行った圧力範囲のデータを元に外挿する場合，あるいは，P>1において Puklin ら の較正式のような特性を有する PSP を使用する場合を想定して考察を行う. 圧力の相対誤差が発散する $P=-B / 2 C$ は，2 章で述べたように $C<0$ から $P>0$ の領域にあるため，実際の計測の際にはP $=-B / 2 C$ 近辺では，すなわち 圧力感度が 0 になるような圧力域では，急速に圧力の相対誤差が増大することに注意しなければならない . Puklin らのデータでは $P=-B / 2 C=2.89$ であり，この点で圧力の相対誤差は発散する . 图 2 から，(2) 式を用いたデータ はP>1 で急激に誤差が大きくなっており，このような Stern-Volmer 関係式のPSPによってP>1での計測を行 うことは不適切であると考えられる.あるいは，2 次式を使用する際，較正実験を行った圧力範囲を元に外捜する ことは不適当であり，実際の計測に際しては注意を要する . 特にin situ 法を用いる場合は，圧力孔で得られる圧 力範囲外となる值は相対誤差が極めて大きくなる可能性に注意する必要がある．また圧力感度が小さくなってし まう圧力 , すなわち $P=-B / 2 C$ を予め把握しておき，光のような圧力域での計測は避けるべきである．

4.2.2 参照圧力 $p_{r e f}$ の誤差が圧力誤差に与える影響

参照画像を撮る際の圧力，参照圧力の誤差による影響は，(2) 式を $p_{r e f}$ にいて偏微分すると，

$$
\frac{\partial p}{\partial p_{r e f}}=\frac{B p+2 C p_{r e f}\left(p / p_{r e f}\right)^{2}}{B p_{r e f}+2 C p}
$$

となり，圧力 $p$ の相対誤差 $\Delta p / p$ は，

$$
\left(\frac{\Delta p}{p}\right)_{p_{\text {ref }}}=\frac{p_{\text {ref }}}{p}\left|\frac{\partial p}{\partial p_{\text {ref }}}\right| \frac{\Delta p_{\text {ref }}}{p_{\text {ref }}}=\frac{\Delta p_{\text {ref }}}{p_{\text {ref }}}
$$

と書ける .このことから ，圧力 $p$ の相対誤差は参照圧力 $p_{r e f}$ の相対誤差に等しくなる . これは (1) 式についての 場合と同樣である .

\subsubsection{Stern-Volmer 係数の誤差が圧力誤差に与える影響}

(1) 式に圧力に関する 2 次の項を加えた (2) 式を用いることによって, 明らかに較正実験データに対する残差 2 乗和を低減できる．しかし通常は高次項の導入により，低次項の係数の標準誤差は増大する ${ }^{(10)}$ こに注意を要す る.Stern-Volmer 係数の相対誤差が圧力の相対誤差に与える影響は , (2) 式を Stern-Volmer 係数 $A, B, C$ にいて 


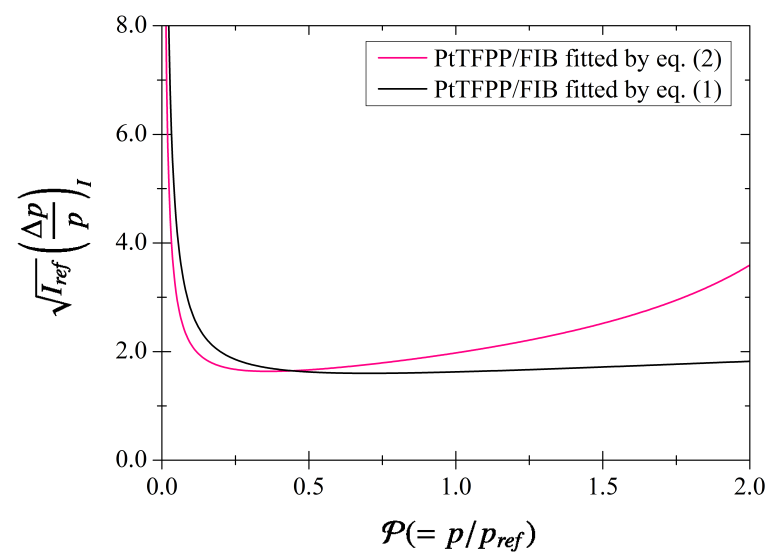

Fig. 2 Relative error in pressure as a function of normalized pressure for the three PSP, PtTFPP/FIB fitted by eq. (2) ( $A=0.096, B=1.081, C=-0.187)$ and eq. (1) $(A=0.13, B=0.87)$.

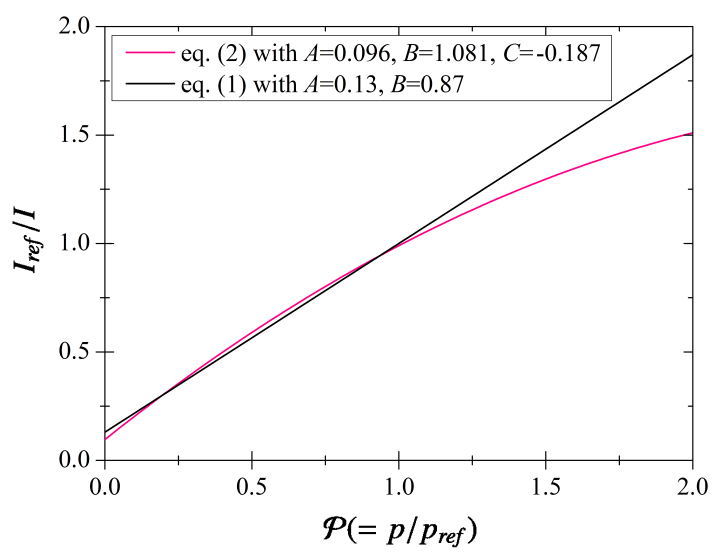

Fig. 3 Stern-Volmer relation represented by eq. (2) $(A=0.096, B=1.081, C=-0.187)$ and eq. (1) $(A=0.13$, $B=0.87)$.

偏微分すると，

$$
\begin{aligned}
& \frac{\partial p}{\partial A}=-\frac{p_{\text {ref }}}{B+2 C \mathcal{P}} \\
& \frac{\partial p}{\partial B}=-\frac{p_{\text {ref }} \mathcal{P}}{B+2 C \mathcal{P}} \\
& \frac{\partial p}{\partial C}=-\frac{p_{\text {ref }} \mathcal{P}^{2}}{B+2 C \mathcal{P}}
\end{aligned}
$$

となる.ここでも $P=p / p_{\text {ref }}$ とおいた . 4.1.3 項では，圧力の相対誤差は近似的に各係数による相対誤差の 2 乗和 の平方根で与えられるとしたが， (2) 式のような 2 次式の場合は, Stern-Volmer 係数の誤差行列はより複雑で, 各 係数間の共分散が圧力誤差に与える影響は実験する圧力範囲やPSP の個々の特性によって異なると考えられる . 光 こでここでは，各係数による相対誤差の絶対值の和を用いて計算することとする .この場合，各係数間にどのよ うな共分散関係が存在していても，この式によって与えられる值を超えることはない．すると，圧力の相対誤差 
$\Delta p / p$ は，

$$
\begin{aligned}
\left(\frac{\Delta p}{p}\right)_{A, B, C} & =\frac{A}{p}\left|\frac{\partial p}{\partial A}\right| \frac{\Delta A}{A}+\frac{B}{p}\left|\frac{\partial p}{\partial B}\right| \frac{\Delta B}{B}+\frac{C}{p}\left|\frac{\partial p}{\partial C}\right| \frac{\Delta C}{C} \\
& =\frac{1}{(B+2 C \mathcal{P}) \mathcal{P}}\left(A \frac{\Delta A}{A}+B \mathcal{P} \frac{\Delta B}{B}+C \mathcal{P}^{2} \frac{\Delta C}{C}\right)
\end{aligned}
$$

となる .ここで圧力感度 $B+2 C P>0$ であることを使った . このときやはり，P $\rightarrow-B / 2 C$ で圧力の相対誤差は発 散する 。

温度 $T_{r e f}$ 近傍での Stern-Volmer 係数の相対誤差が圧力の相対誤差に与える影響は , (2) 式の場合も 4.1.3 項と同 樣に評価出来る .すなわち (2) 式に $A_{r e f}+B_{r e f}+C_{r e f}=1$ なる拘束条件のある場合であり，

$$
\frac{I_{\text {ref }}}{I}=1-B_{\text {ref }}-C_{\text {ref }}+B_{\text {ref }} \frac{p}{p_{\text {ref }}}+C_{\text {ref }}\left(\frac{p}{p_{\text {ref }}}\right)^{2}
$$

について考える．上式をを $B_{r e f}, C_{r e f}$ について偏微分し整理すると，

$$
\begin{gathered}
\frac{\partial p}{\partial B_{r e f}}=\frac{p_{r e f}(1-\mathcal{P})}{B_{r e f}+2 C_{r e f} \mathcal{P}} \\
\frac{\partial p}{\partial C_{r e f}}=\frac{p_{r e f}\left(1-\mathcal{P}^{2}\right)}{B_{r e f}+2 C_{r e f} \mathcal{P}}
\end{gathered}
$$

が得られる . 圧力の相対誤差 $\Delta p / p$ は，先の場合に合わせて各係数による相対誤差の絶対值の和をとり，

$$
\begin{aligned}
\left(\frac{\Delta p}{p}\right)_{B, C} & =\frac{B_{r e f}}{p}\left|\frac{\partial p}{\partial B_{r e f}}\right| \frac{\Delta B_{r e f}}{B_{r e f}}+\frac{C_{r e f}}{p}\left|\frac{\partial p}{\partial C_{r e f}}\right| \frac{\Delta C_{r e f}}{C_{r e f}} \\
& =\left|\frac{1}{\mathcal{P}}-1\right| \frac{1}{B_{r e f}+2 C_{r e f} \mathcal{P}}\left(B_{r e f} \frac{\Delta B_{r e f}}{B_{r e f}}+C_{r e f}(1+\mathcal{P}) \frac{\Delta C_{r e f}}{C_{r e f}}\right)
\end{aligned}
$$

で与えられることから，このときも $\mathcal{P}\left(=p / p_{r e f}\right)=1$ 近傍で相対誤差が極めて小さくなることが分かり，(2) 式を用 いる場合においても拘束条件として $A_{r e f}+B_{r e f}+C_{r e f}=1$ を課した方が有利であることが分かる.

4.2.4 温度の誤差が圧力誤差に与える影響

次に温度の相対誤差が圧力の相対誤差に与える影響を調べる.やはり，Stern-Volmer 係数が温度の関数であるこ とに注意して (2) 式を温度 $T$ について偏微分する。

$$
\frac{\partial p}{\partial T}=\frac{p_{r e f}}{B+2 C \mathcal{P}}\left(-\frac{\partial A}{\partial T}-\mathcal{P} \frac{\partial B}{\partial T}-\mathcal{P}^{2} \frac{\partial C}{\partial T}\right)
$$

すると圧力 $p$ の相対誤差 $\Delta p / p$ は，

$$
\left(\frac{\Delta p}{p}\right)_{T}=\frac{T}{p}\left|\frac{\partial p}{\partial T}\right| \frac{\Delta T}{T}=\frac{T}{(B+2 C \mathcal{P}) \mathcal{P}}\left|-\frac{\partial A}{\partial T}-\mathcal{P} \frac{\partial B}{\partial T}-\mathcal{P}^{2} \frac{\partial C}{\partial T}\right| \frac{\Delta T}{T}
$$

で与えられる.この場合も，P(= $\left.p / p_{r e f}\right) \rightarrow-B / 2 C$ で相対誤差が発散し，著しく誤差が大きくなることが分かる .

4.3 Stern-Volmer 関係式を線形, 非線形式としたときの相対誤差の比較

4.3.1 一般の場合での相対誤差の比較

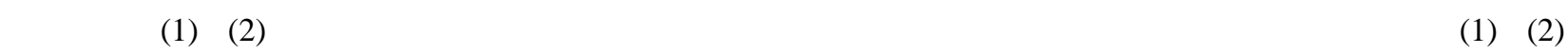
式のいずれを用いる場合が良いのかについて調査を行う. 圧力の相対誤差 $\Delta p / p$ は, 前節までに議論した, 発光強 度 $I$, 参照圧力 $p_{r e f}$, Stern-Volmer 係数 $A, B, C$, 温度 $T$ の光れ帒れの相対誤差による圧力の相対誤差を合わせた ものである .一般に各パラメータ間の共分散関係を求めるのは困難であるため，ここでは簡単のため圧力の相対 誤差は各要素によるものの和で表わされるとする . このときやはり相対誤差は最大值を与えるものとなり, 各要 素間の共分散関係がどのような值をとってもこの值を超えることはない . すなわち圧力の相対誤差 $\Delta p / p$ は ,

$$
\left(\frac{\Delta p}{p}\right)=\left(\frac{\Delta p}{p}\right)_{I}+\left(\frac{\Delta p}{p}\right)_{A, B, C}+\left(\frac{\Delta p}{p}\right)_{p_{\text {ref }}}+\left(\frac{\Delta p}{p}\right)_{T}
$$


で与えられる．ここで添え字は発光強度 $I$ など上記に述べた各要素を表す.Stern-Volmer 関係式に (1)，(2) 式を用 いた場合の圧力の相対誤差を乥れ光れ $(\Delta p / p)_{f},(\Delta p / p)_{s}$ と表わせば，前節までの議論から

$$
\begin{aligned}
\left(\frac{\Delta p}{p}\right)_{f} & =\frac{\alpha}{\sqrt{I_{\text {ref }}}} \frac{A_{f}+B_{f} \mathcal{P}}{B_{f} \mathcal{P}} \sqrt{1+A_{f}+B_{f} \mathcal{P}}+\frac{\Delta p_{\text {ref }}}{p_{\text {ref }}}+\sqrt{\frac{A_{f}^{2}}{B_{f}^{2}}} \frac{1}{\mathcal{P}^{2}}\left(\frac{\Delta A_{f}}{A_{f}}\right)^{2}+\left(\frac{\Delta B_{f}}{B_{f}}\right)^{2}+\frac{T}{B_{f} \mathcal{P}}\left|-\frac{\partial A_{f}}{\partial T}-\mathcal{P} \frac{\partial B_{f}}{\partial T}\right| \frac{\Delta T}{T} \\
\left(\frac{\Delta p}{p}\right)_{s} & =\frac{\alpha}{\sqrt{I_{\text {ref }}}} \frac{A_{s}+B_{s} \mathcal{P}+C_{s} \mathcal{P}^{2}}{\left(B_{s}+2 C_{s} \mathcal{P}\right) \mathcal{P}} \sqrt{1+A_{s}+B_{s} \mathcal{P}+C_{s} \mathcal{P}^{2}}+\frac{\Delta p_{r e f}}{p_{r e f}} \\
& +\frac{1}{\left(B_{s}+2 C_{s} \mathcal{P}\right) \mathcal{P}}\left(A_{s} \frac{\Delta A_{s}}{A_{s}}+B_{s} \mathcal{P} \frac{\Delta B_{s}}{B_{s}}+C_{s} \mathcal{P}^{2} \frac{\Delta C_{s}}{C_{s}}\right)+\frac{T}{\left(B_{s}+2 C_{s} \mathcal{P}\right) \mathcal{P}}\left|-\frac{\partial A_{s}}{\partial T}-\mathcal{P} \frac{\partial B_{s}}{\partial T}-\mathcal{P}^{2} \frac{\partial C_{s}}{\partial T}\right| \frac{\Delta T}{T}
\end{aligned}
$$

と書ける．ここでは紛らわしさの回避のため，(1)，(2) 式に重複して現れる Stern-Volmer 係数に添え字 $f, s$ を光 れぞれ付した .一般に $\Delta p_{\text {ref }} / p_{\text {ref }}$ は高精度な圧力計を使用することによって十分に小さくできるため，この項は無 視することができる. 実際の計測の際には, 上式を計算し (1), (2) 式のどちらが優位かを確かめる必要がある . こ こで図 2 に再度注目すると，発光強度の相対誤差に関しては広い領域において (1) 式を用いた場合の方が有利であ ることが分かる . また先に指摘したように, あてはめの際に高次項を加えると, 低次項の係数の誤差は一般に増 大する .この点に注目すると，(33)，(34) 式の第 3 項の Stern-Volmer 係数に関する誤差の項は (2) 式を用いた場合 にもあまり改善は望めず，(1)式を用いた場合の方が有利であると考えられる．すなわち，(1) 式によるあてはめに おいて Stern-Volmer 係数の誤差が小さいならば，(1) 式を用いた方が良いと言え，不必要な高次化は誤差の増大を もたらす．

4.3.2 $T \approx T_{r e f}$ での相対誤差の比較

$T \approx T_{r e f}$ のとき, $A_{r e f}+B_{r e f}+C_{r e f}=1$ などの拘束条件を課すことが可能となり，(1)，(2) 式を用いた場合の圧力 の相対誤差 $(\Delta p / p)_{f},(\Delta p / p)_{s}$ は光れ光れ，

$$
\begin{aligned}
\left(\frac{\Delta p}{p}\right)_{f} & =\frac{\alpha}{\sqrt{I_{r e f}}} \frac{1-B_{f}+B_{f} \mathcal{P}}{B_{f} \mathcal{P}} \sqrt{2-B_{f}+B_{f} \mathcal{P}}+\frac{\Delta p_{r e f}}{p_{\text {ref }}}+\left|\frac{1}{\mathcal{P}}-1\right| \frac{\Delta B_{f}}{B_{f}}+\frac{T_{r e f}}{B_{f} \mathcal{P}}\left|(1-\mathcal{P}) \frac{\partial B_{f}}{\partial T}\right| \frac{\Delta T_{\text {ref }}}{T_{\text {ref }}} \\
\left(\frac{\Delta p}{p}\right)_{s} & =\frac{\alpha}{\sqrt{I_{\text {ref }}}} \frac{1-B_{s}-C_{s}+B_{s} \mathcal{P}+C_{s} \mathcal{P}^{2}}{\left(B_{s}+2 C_{s} \mathcal{P}\right) \mathcal{P}} \sqrt{2-B_{s}-C_{s}+B_{s} \mathcal{P}+C_{s} \mathcal{P}}+\frac{\Delta p_{r e f}}{p_{r e f}} \\
& +\left|\frac{1}{\mathcal{P}}-1\right| \frac{1}{B_{s}+2 C_{s} \mathcal{P}}\left(B_{s} \frac{\Delta B_{s}}{B_{s}}+C_{s}(1+\mathcal{P}) \frac{\Delta C_{s}}{C_{s}}\right)+\frac{T_{r e f}}{\left(B_{s}+2 C_{s} \mathcal{P}\right) \mathcal{P}}\left|(1-\mathcal{P}) \frac{\partial B_{s}}{\partial T}+\left(1-\mathcal{P}^{2}\right) \frac{\partial C_{s}}{\partial T}\right| \frac{\Delta T_{r e f}}{T_{r e f}}
\end{aligned}
$$

と書ける . 見易さのため添え字 ref は省略したが，ここで現れる Stern-Volmer 係数は全て $T_{r e f}$ での值である . ま た (1)，(2) 式に重複して現れる Stern-Volmer 係数に添え字 $f, s$ を光れ光れ付した．温度が一定と見なせる場合は 上式によって圧力の相対誤差を見積もることができる．

4.3.3 $T \approx T_{\text {ref }}$ かつ $p \approx p_{\text {ref }}$ での相対誤差の比較

$T \approx T_{\text {ref }}$ かつP $\mathcal{P}\left(=p / p_{\text {ref }}\right) \approx 1$ のとき, (1), (2) 式のどちらを用いる場合が計測誤差を小さくできるかについて考 える.P $=1+\varepsilon$ と微小量 $\varepsilon$ を用いて漸近展開し $\varepsilon$ のオーダーの項を無視すると，(35)，(36) 式は光れ光れ

$$
\begin{aligned}
& \left(\frac{\Delta p}{p}\right)_{f} \approx \frac{\alpha}{\sqrt{I_{r e f}}} \frac{\sqrt{2}}{B_{f}}+O(\varepsilon) \\
& \left(\frac{\Delta p}{p}\right)_{s} \approx \frac{\alpha}{\sqrt{I_{r e f}}} \frac{\sqrt{2}}{B_{s}+2 C_{s}}+O(\varepsilon)
\end{aligned}
$$

と書ける . 両式を比較すると，

$$
B_{f}>B_{s}+2 C_{s}
$$

のとき， $(\Delta p / p)_{f}<(\Delta p / p)_{s}$ となり，P $\approx 1$ において (1) 式を用いた方が計測誤差が少なくなることが分かる .この 樣子は (33)，(34) 式の第 1 項を比較した図 2 において確認でき， $B_{f}=0.87, B_{s}=1.081, C_{s}=-0.187$ より確かに (39) 式の条件を満たしている.

$$
\text { 5.おわりに }
$$

本研究では, PSP 計測における Stern-Volmer 関係式の較正法及び誤差伝播について調査を行った . 特に , (2) 式 のように Stern-Volmer 関係式を非線形とした場合の誤差解析については他に報告例がなく，重要な知見である . 本 研究で得られた知見を以下にまとめる. 
1. 較正法について，実験值を各種 Stern-Volmer 関係式であてはめる際に, $T=T_{\text {ref }}$ においては $\left(p / p_{\text {ref }}, I_{\text {ref }} / I\right)=(1,1)$ を通るような拘束条件を課すべきことを指摘するとともに，各画素毎に圧力感度を計算し，弚の後，ある領域 内で空間平均をとり Stern-Volmer 関係式を得る手法によって較正実験の不備等が発見し易いことを指摘した 。 また十分広い領域において空間平均をとることによって，ランダム誤差の影響をほとんど除き Stern-Volmer 関係式で実験值のあてはめを行うことができることを指摘した .

2. Stern-Volmer 関係式を (1) 式のような線形式で表現する場合, 発光強度誤差及び温度誤差の観点から，PSP の 圧力感度 $B$ が大きい方が計測には有利であることが明らかとなった . ただし $p / p_{r e f} \rightarrow 0$ で相対誤差が発散す るため，低圧での計測には注意が必要である．また実験值を近似し Stern-Volmer 係数を計算する際， $T=T_{r e f}$ においては $\left(p / p_{\text {ref }}, I_{r e f} / I\right)=(1,1)$ を通るような拘束条件 $A_{r e f}+B_{r e f}=1$ を課した方が, Stern-Volmer 係数の相 対誤差は拘束条件がない場合よりも大きくなるにも関わらず $p / p_{r e f}=1$ 近傍において圧力の相対誤差を小さく することができることを示した .

3. Stern-Volmer 関係式を (2) 式とする場合，各パラメータの相対誤差が圧力の相対誤差に与える影響は, (1) 式を用いる場合とほぼ同樣の傾向を示すことが分かり， $T=T_{\text {ref }}$ においては, 各々の Stern-Volmer 関係式が $\left(p / p_{\text {ref }}, I_{r e f} / I\right)=(1,1)$ を通るような拘束条件 $A_{r e f}+B_{r e f}+C_{r e f}=1$ を課すことによって,$p / p_{r e f}=1$ 近傍での相 対誤差を小さくすることができることを明らかにした .しかし一方で, $p / p_{r e f} \rightarrow-B / 2 C$ において急速に相対 誤差が増大するため，使用する圧力域と Stern-Volmer 関係式の関係に十分な注意を払う必要があることを指 摘した .

4. Stern-Volmer 関係式を (1)，(2) 式のいずれを使用すべきかについて議論し，(1) 式を用いた際の Stern-Volmer

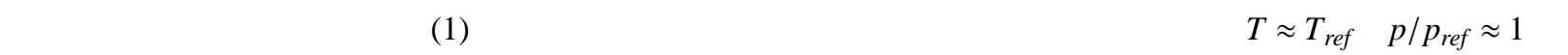
とき，弚の判断基準となる関係式を導出した .

謝 辞

本研究は一部に科学研究費補助金及びマツダ財団の助成を受けて実施した．ここに記して謝意を表する．

文献

(1) Bell, J.H., Schairer, E.T., Hand, L.A., and Mehta, R.D., "Surface Pressure Measurements using Luminescent Coatings", Annual Review of Fluid Mechanics, Vol. 33 (2001), pp. 155-206.

(2) Liu, T., and Sullivan, J.P., Pressure and Temperature Sensitive Paints (2004), Springer-Verlag, Berlin.

(3) Nagai, H., Naraoka, R., Sawada, K., and Asai, K., "Pressure-Sensitive Paint Measurement of Pressure Distribution in a Supersonic Micronozzle", AIAA Journal, Vol. 46, No. 1 (2008), pp. 215-222.

(4) Matsuda, Y., Uchida, T., Suzuki, S., Misaki, R., Yamaguchi, H., and Niimi, T., “ Pressure-Sensitive Molecular Film for Investigation of Micro Gas Flows", Microfluidics and Nanofluidics, Vol. 10, No. 1 (2010), pp. 165-171.

(5) 亀谷知宏, 松田佑, 山口浩樹, 江上泰広, 新美智秀“; 感圧塗料を用いた高速回転ディスク表面の圧力分布計測”, 日本 機械学会論文集 C 編，Vol. 76 , No. 771 (2010), pp. 3002-3007.

(6) Oglesby, D.M., Puram, C.K., and Upchurch, B.T., Optimization of Measurements with Pressure Sensitive Paints, NASA Technical Memorandum 4695 (1995).

(7) Taylor, J.R. 著, 林茂雄, 馬場涼, 訳 , “計測における誤差解析入門”, 東京化学同人 (2000).

(8) 田島稔, 小牧和雄, 最小二乗法の理論と炎の応用 (1987), p. 186 , 東洋書店 .

(9) Puklin, E., Carlson, B., Gouin, S., Costin, C., Green, E., Ponomarev, S., Tanji, H, and Gouterman, M., "Ideality of PressureSensitive Paint. I. Platinum Tetra(pentafluorophenyl)porphine in Fluoroacrylic Polymer", Journal of Applied Polymer, Vol. 77, No. 13 (2000), pp. 2795-2804.

（10）中川徹, 小柳義夫, 最小二乗法による実験データ解析 (1982), p. 141 , 東京大学出版会. 